\title{
Copper Rich Composite Materials Based on Carboxylic Cation Exchangers and Their Thermal Transformation
}

\author{
Elżbieta Kociołek-Balawejder ${ }^{1, *(D)}$, Ewa Stanisławska ${ }^{1}$, Irena Jacukowicz-Sobala ${ }^{1}$ (D) and Igor Mucha ${ }^{2} \mathbb{D}$ \\ 1 Department of Industrial Chemistry, Wroclaw University of Economics and Business, \\ 53-345 Wrocław, Poland; ewa.stanislawska@ue.wroc.pl (E.S.); irena.jacukowicz@ue.wroc.pl (I.J.-S.) \\ 2 Department of Analytical Chemistry, Wroclaw Medical University, 50-556 Wrocław, Poland; \\ igor.mucha@umed.wroc.pl \\ * Correspondence: elzbieta.kociolek-balawejder@ue.wroc.pl
}

check for updates

Citation: Kociołek-Balawejder, E.; Stanisławska, E.; Jacukowicz-Sobala, I.; Mucha, I. Copper Rich Composite Materials Based on Carboxylic Cation Exchangers and Their Thermal Transformation. Polymers 2021, 13, 3199. https://doi.org/10.3390/ polym13183199

Academic Editors: Hamed

Yazdani Nezhad, Mohamad Fotouhi and Han Zhang

Received: 25 August 2021

Accepted: 15 September 2021

Published: 21 September 2021

Publisher's Note: MDPI stays neutral with regard to jurisdictional claims in published maps and institutional affiliations.

Copyright: (c) 2021 by the authors. Licensee MDPI, Basel, Switzerland. This article is an open access article distributed under the terms and conditions of the Creative Commons Attribution (CC BY) license (https:/ / creativecommons.org/licenses/by/ $4.0 /)$.

\begin{abstract}
The effect of a cupric deposit $\left(\mathrm{Cu}^{2+}, \mathrm{CuO}\right)$ on the thermal decomposition of carboxylic cation exchangers (CCEs) is not known, and such studies may have practical significance. CCEs have a very high ion exchange capacity, so an exceptionally large amount of $\mathrm{CuO}$ (which is a catalyst) can be precipitated inside them. Two CCEs, macroreticular (Amberlite IRC50) and gel-like (Amberlite IRC86), served as a polymeric support to obtain copper-rich hybrid ion exchangers. Composites with $\mathrm{CuO}$ particles inside a polyacrylic matrix (up to $35.0 \mathrm{wt} \% \mathrm{Cu}$ ) were obtained. Thermal analyses under air and under $\mathrm{N}_{2}$ were performed for CCEs in the $\mathrm{H}^{+}$and $\mathrm{Cu}^{2+}$ form with and without a $\mathrm{CuO}$ deposit. The results of sixteen experiments are discussed based on the TG/DTG curves and XRD patterns of the solid residues. Under air, the cupric deposit shifted the particular transformations and the ultimate polymeric matter decomposition (combustion) toward lower temperatures (even about $100-150{ }^{\circ} \mathrm{C}$ ). Under $\mathrm{N}_{2}$, the reduction of the cupric deposit to metallic copper took place. Unique composite materials enriched in carbonaceous matter were obtained, as the products of polymeric matrix decomposition (free radicals and hydrogen) created an additional amount of carbon char due to the utilization of a certain amount of hydrogen to reduce $\mathrm{Cu}$ (II) to $\mathrm{Cu}^{0}$.
\end{abstract}

Keywords: carboxylic cation exchanger; cuprous oxide; metallic copper; composite; thermal analysis; incineration; pyrolysis

\section{Introduction}

Activated carbon, biochar, zeolite, synthetic polymers, and biopolymers supporting metal oxide nanoparticles are modern and effective composite materials that offer properties and application opportunities not exhibited separately by the individual componentshigh molecular weight host materials or inorganic nanoparticles alone [1-6]. The composite materials display more advantageous properties than raw supporting materials, allowing the effective removal of troublesome organic contaminants, such as antibiotics, dyes, and pesticides, and also toxic metallic and nonmetallic substances from aqueous media [7-10].

By dispersing metal oxide nanoparticles into an ion exchanger matrix, hybrid ion exchangers (HIXs) can be prepared. Due to their form of porous spherical beads with mechanical strength and due to overcoming the propensity of parent nanoparticles to aggregate (by isolating them within the polymeric skeleton), HIXs are suitable for batch and flow-through systems, providing a highly accessible surface area, high sorption capacity, fast kinetics, and enhanced selectivity in purification processes (the Donnan membrane effect controls what type of ions can enter inside the resin structure) [11]. The different morphology of the host materials (ion exchanger macroreticular vs. gel-like structure), the diverse nature and concentration of the ionogenic functional groups (strongly or weakly acidic vs. strongly or weakly basic), the various methods of dispersing metal oxide NPs inside the polymer support, and the specific properties of immobilized metal oxide nanoparticles all contribute to the diversity of their applications, including separation 
processes, catalysis and biocidal actions [12-17]. The most popular HIXs are $\mathrm{FeOOH}$, $\mathrm{MnO}_{2}$, and $\mathrm{ZrO}_{2}$ doped anion exchangers. They are used to remove arsenic species and various harmful oxyanions from water through sorption and redox processes [18-20].

The introduction of metal oxides into the ion exchanger matrix can have various consequences, including catalysis related. In 2002, a study demonstrated that metal compounds including $\mathrm{CuSO}_{4} \cdot 5 \mathrm{H}_{2} \mathrm{O}, \mathrm{CuO}$, and $\mathrm{FeSO}_{4} \cdot 7 \mathrm{H}_{2} \mathrm{O}$ (mixed with ionite), as well as $\mathrm{Cu}^{2+}$ ions pre-loaded on the resin, had a catalytic effect on the oxidative pyrolysis of cationic (sulfonic) resin, in which the decomposition of functional groups and polymer matrices was enhanced [21]. Thermal decomposition of ion exchangers by combustion or pyrolysis is one of the possibilities for the treatment and disposal of spent ion exchangers, reducing their volume [22-25], making the waste more stable [26,27] and giving usable porous carbon beads [28-32]. Handling spent ion exchangers is especially environmentally significant if they come from nuclear power plants and constitute a highly radioactive waste [33-36]. Considering the catalytic properties of copper compounds and also the necessity to develop methods of treatment of the used ion exchangers, we have undertaken research on the synthesis and thermal decomposition of HIXs under air and under $\mathrm{N}_{2}$, in which, as host materials for $\mathrm{CuO}, \mathrm{Cu}(\mathrm{OH})_{2}, \mathrm{Cu}_{4}(\mathrm{OH})_{6} \mathrm{SO}_{4}, \mathrm{Cu}_{2} \mathrm{O}$, and $\mathrm{Cu}^{0}$ fine particles, strongly basic anion exchangers with macroreticular and gel-like structure were used [37-39]. It turned out that copper compounds deposited in the skeleton of such resins significantly altered the results of the thermal analysis in comparison with those of pure resin $[40,41]$. The differences resulted from the process end temperature, the acceleration of the decomposition steps, the amount of carbonizate in the post-pyrolysis residue, and also the composition of the inorganic phase ( $\mathrm{CuO}$ after combustion, $\mathrm{Cu}^{0}$ after pyrolysis). It was demonstrated that during the thermal decomposition of the HIXs under $\mathrm{N}_{2}$, the oxidation state of the copper atom in the deposit had an increasing effect (cupric compounds > cuprous compounds $>$ metallic copper) on the amount of the forming char. Owing to the hydrogen-consuming conversion (reduction of copper compounds occurred), much more carbonizate formed than in the pyrolysis of pure resin. It has been shown that it is possible to use thermal processes for transforming spent HIXs into carbonaceous materials containing a substantial amount of metallic copper-potential reagents for purification and catalytic processes [42-44].

Considering the beneficial effect of $\mathrm{CuO}$ particles on the speed of thermal decomposition and the mass of solid residue formed during HIX pyrolysis, we have expanded research on this issue by synthesizing materials that may contain a much larger amount of this oxide than before, which can also give residual carbonaceous materials extremely rich in metallic copper. As polymeric hosts, carboxylic cation exchangers (CCEs) with $-\mathrm{COOH}$ groups having both macroreticular and gel-like structure were used. As a result of the low molecular weight of the aliphatic carboxylic acid (acrylic acid or methacrylic acid) forming the polymeric skeleton, their ion exchange capacity (the number of ionogenic groups per mass unit) is several times higher than the sorption capacity of anion exchangers with trimethyl ammonium functional groups used previously as support for $\mathrm{CuO}$ [45-47]. As regards the synthesis of cationites with a $\mathrm{CuO}$ deposit, this has so far only been performed for strongly acidic sulfonic cationite receiving HIX for low-concentration ammonia nitrogen removal from water [48]. A CCE with a CuO deposit has not yet been described, but the stabilization of metallic copper nanoparticles inside the CCE matrix has been reported $[49,50]$.

CCEs are weakly acidic resins, highly selective with respect to the $\mathrm{H}^{+}$ion and in contrast with strongly acidic ones, first of all sorb hydrogen ions from among all cations (in this form, they do not split neutral salts). A small, stoichiometric excess of a strong mineral acid is sufficient to convert the resin into the $\mathrm{H}^{+}$form. The degree of ionization of their less-dissociated active groups corresponds to that of acetic acid. The effective $\mathrm{pH}$ range is between 6 and 14. A relatively high degree of affinity exists for the earth alkaline metal ions. CCEs are used primarily for the removal of cations from basic solutions (dealkalization, softening of high salinity waters), for the splitting of weakly alkaline salts 
of polyvalent cations, and also for the isolation and purification of biochemicals such as antibiotics, vitamins, alkaloids, and enzymes [51-55]. The use of CCEs for reducing the volume of radioactive waste generated in nuclear power plants was also considered [56,57].

Given the high sorption capacity of CCEs (which is many times higher than other ion exchange resins), the aim of this work was to synthesize HIXs rich in $\mathrm{CuO}$ fine particles and examine their thermal properties compared to pure resins. The research was intended to answer the following questions. How much $\mathrm{CuO}$ can be introduced into the skeleton of both cationites, and does the gel-type structure limit the mass of this deposit? Can CCEs containing $\mathrm{CuO}$ be used in the $\mathrm{H}^{+}$form without losing the deposit? What is the effect of the ionic form of the functional groups $\left(\mathrm{Cu}^{2+}, \mathrm{H}^{+}\right)$and $\mathrm{CuO}$ deposit on the decomposition of both resins under air and $\mathrm{N}_{2}$ atmospheres? During pyrolysis, will the cracked polyacrylic matrix containing - $\mathrm{COOH}$ groups (with oxygen atoms) reduce $\mathrm{Cu}$ (II) and create an additional amount of carbon char (as in the case of polystyrene matrix of anion exchange resins)? What is the mass and composition of the solid residue depending on the thermal analysis atmosphere?

The research described here concerns the synthesis of HIXs particularly rich in a cupric deposit, shows the effects of various factors on the thermal decomposition of synthesized composite materials, and is also related to an important area of modern researchcarbothermal synthesis of metal-char composites, which are forward-looking materials. Thanks to the presence of dispersed metallic copper fine particles within the carbonaceous phase, they represent reagents that can be useful for mediating environmentally important processes.

\section{Materials and Methods}

\subsection{Materials}

The polymeric supports for $\mathrm{CuO}$ were Amberlite IRC50 (macroporous) and Amberlite IRC86 (gel-like), commercial weakly acidic cation exchangers produced by The Dow Chemical Co. (Table 1). All the chemicals used in this study, including $\mathrm{CuSO}_{4} \cdot 5 \mathrm{H}_{2} \mathrm{O}, \mathrm{CH}_{3} \mathrm{COOH}$ $80 \%$, an analytically weighed amount of ethylenediaminetetraacetic acid disodium salt dihydrate (EDTA) $0.05 \mathrm{M}$ (Chempur, Piekary Śląskie, Poland), murexide (Eurochem, Tarnów, Poland), $\mathrm{HCl} 35-38 \%$, ammonia solution $25 \%$, and $\mathrm{NaOH}$ (PPH Stanlab, Lublin, Poland), were of analytical grade. All the solutions were prepared using deionized water.

Table 1. Characterization of polymeric materials.

\begin{tabular}{ccc}
\hline Properties & Amberlite IRC 50 & Amberlite IRC 86 \\
\hline Appearance & Beige opaque spherical beads & Clear amber translucent spherical beads \\
\hline Particle size, mesh & $16-50$ & $20-50$ \\
\hline Matrix type & Methacrylic acid-DVB & Acrylic acid-DVB \\
\hline Matrix structure & Macroporous (M) & Gel-like (G) \\
\hline Functional groups & Carboxylic in $\mathrm{H}^{+}$form $(\mathrm{M} / \mathrm{H}, \mathrm{G} / \mathrm{H})$ \\
\hline Total exchange capacity by dry weight, meq/g & 10.5 & 10.7 \\
\hline Total reversible swelling, $\%$ & $\mathrm{H}^{+} \rightarrow \mathrm{Na}^{+}, 100$ & $\mathrm{H}^{+} \rightarrow \mathrm{Na}^{+}, 80$ \\
\hline
\end{tabular}

\subsection{Synthesis of HIXs}

Before chemical transformation, the $\mathrm{M} / \mathrm{H}$ and $\mathrm{G} / \mathrm{H}$ samples (i.e., the functional groups of cationites in the $\mathrm{H}^{+}$form) were soaked and washed with distilled water and dried in a dryer at $40{ }^{\circ} \mathrm{C}$ for $24 \mathrm{~h}$. Both resins were transformed in five stages. Four of the transformations (A, B, D, and E) consisted of ion exchange, quantitatively carried out on the functional groups of the cationite in the $\mathrm{Na}^{+}, \mathrm{Cu}^{2+}$ and back in the $\mathrm{H}^{+}$form using solutions such as $1 \mathrm{M} \mathrm{NaOH}, 0.1 \mathrm{M} \mathrm{CuSO}_{4}$, and $0.05 \mathrm{M} \mathrm{CH}_{3} \mathrm{COOH}$. In each case, the process was conducted in a column until the concentrations of effluent and influent were 
approximately the same. Stage $\mathrm{C}$, consisting of precipitating $\mathrm{CuO}$ in the resin matrix, was conducted batchwise, shaking for $4 \mathrm{~h} \mathrm{M} / \mathrm{Cu}$ or $\mathrm{G} / \mathrm{Cu}$ with excess of $1 \mathrm{M} \mathrm{NaOH}$ at ambient temperature. The sequence of transformations is illustrated in Scheme 1.

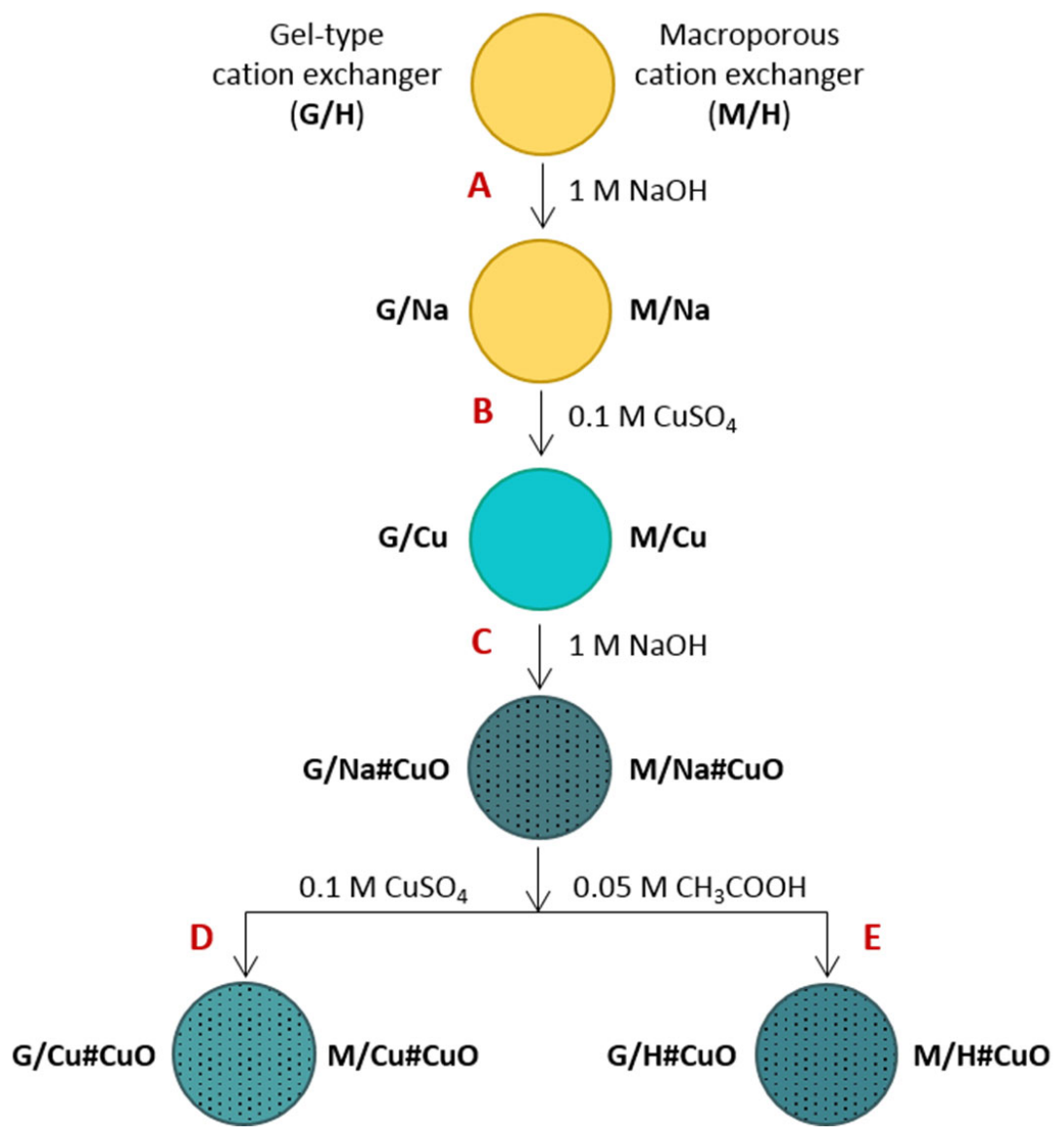

Scheme 1. Synthesis of HIXs containing $\mathrm{CuO}$ deposit within the matrix of carboxylic cation exchangers (A, B, D, E-ion exchange reactions, $\mathrm{C}$-precipitation of $\mathrm{CuO}$ in alkaline medium).

The $\mathrm{Cu}$ content in the samples was determined after dissolving the cupric deposit in $2 \mathrm{M} \mathrm{HCl}$ ( $0.5 \mathrm{~g}$ sample, $20 \mathrm{~cm}^{3}$ solution, $30 \mathrm{~min}$ of shaking). The solution was alkalized with concentrated ammonia solution and titrated with 0.05 M EDTA against murexide.

\subsection{Thermogravimetric Analysis}

The thermogravimetric experiment was carried out using a TG 209 F1 Libra thermogravimetric analyzer (Netzsch, Selb, Germany). For the thermogravimetric analysis (TG/DTG), the samples were placed in an alumina crucible $(150 \mu \mathrm{L})$. About $14 \mathrm{mg}$ of sample was heated from an ambient temperature up to $950{ }^{\circ} \mathrm{C}$ at a heating rate of $10^{\circ} \mathrm{C} / \mathrm{min}$. Experiments were performed in a nitrogen atmosphere $(30 \mathrm{~mL} / \mathrm{min})$ and in an oxidative atmosphere (protective gas—nitrogen $10 \mathrm{~mL} / \mathrm{min}$, and purge gas—air $30 \mathrm{~mL} / \mathrm{min}$ ). The measurements were performed under exactly the same conditions and repeated to determine their reproducibility, which was found to be very good. The sample curves were analyzed using Netzsch Proteus 7.1.0 software (Selb, Germany) The temperatures and mass changes were given with an accuracy (standard deviation) of $\pm 1.5 \mathrm{~K}$ and $0.4 \%$, respectively.

\subsection{X-ray Powder Diffraction Analysis}

The Bruker D2 Phaser X-ray diffractometer (Bruker AXS, Karlsruhe, Germany) operating in Bragg-Brentano $(\theta / 2 \theta)$ geometry, equipped with a LYNXEYE detector (based on silicon strip technology) and copper anode $(\mathrm{Cu}-\mathrm{K} \alpha)$, was used to collect the data for this study. The powdered samples were analyzed on a zero-background sample holder. All 
measurements were taken at room temperature using a step scan mode with the step of $0.02^{\circ}(2 \theta)$ and $0.2 \mathrm{~s}$ per step across the angular range $5^{\circ} \leq(2 \theta) \leq 70^{\circ}$. The optics of the D2 PHASER diffractometer comprised a system of a Soller slit module with $2.5^{\circ}$, a divergence slit with $0.6 \mathrm{~mm}$ and a nickel filter. The X-ray tube operated at $30 \mathrm{kV}$ and $10 \mathrm{~mA}$. The collected XRD patterns were evaluated using Diffrac.EVA v.3.2 (Bruker AXS, Karlsruhe, Germany) software.

\section{Results and Discussion}

\subsection{Hybrid Polymer Formation}

To obtain novel HIXs with high $\mathrm{CuO}$ content, we used two carboxyl cation exchangers (Table 1), which show the highest ion exchange capacity (almost $11.0 \mathrm{meq} / \mathrm{g}$ ) among mass-produced ion exchangers. These resins contained the same functional groups and in a comparable amount, but they differed in the structure and chemical composition of the polymeric skeleton. The matrix of the macroreticular cation exchanger was obtained by polymerizing a methacrylic acid with divinylbenzene (DVB) as a cross-linking agent, whereas the matrix of the gel-like cation exchanger was obtained by polymerizing an acrylic acid with DVB (the precise producer data concerning the cross-linking degree value are not known). The acrylic resins are slightly more strongly acidic (more dissociated, $\mathrm{pK}_{\mathrm{a}}$ 4.8) than the methacrylic acid products (less dissociated, $\mathrm{pK}_{\mathrm{a}}$ 5.7) [58].

Reaction equations illustrate the transformations to which both cation exchangers were subjected to dope $\mathrm{CuO}$ Equations (1)-(5):

$$
\begin{gathered}
{[\mathrm{P}]-\mathrm{COOH}+\mathrm{NaOH} \rightarrow[\mathrm{P}]-\mathrm{COONa}+\mathrm{H}_{2} \mathrm{O}} \\
2[\mathrm{P}]-\mathrm{COONa}+\mathrm{CuSO}_{4} \rightarrow([\mathrm{P}]-\mathrm{COO})_{2} \mathrm{Cu}+\mathrm{Na}_{2} \mathrm{SO}_{4} \\
([\mathrm{P}]-\mathrm{COO})_{2} \mathrm{Cu} \stackrel{\text { excess }}{\rightarrow} \underset{ }{2}\{2[\mathrm{P}]-\mathrm{COONa}\} \# \mathrm{CuO} \\
\{2[\mathrm{P}]-\mathrm{COONa}\} \# \mathrm{CuO}+\mathrm{CuSO}_{4} \rightarrow([\mathrm{P}]-\mathrm{COO})_{2} \mathrm{Cu} \# \mathrm{CuO}+\mathrm{Na}_{2} \mathrm{SO}_{4} \\
{[\mathrm{P}]-\mathrm{COONa} \mathrm{CuO}+\mathrm{CH}_{3} \mathrm{COOH} \rightarrow[\mathrm{P}]-\mathrm{COOH} \# \mathrm{CuO}+\mathrm{CH}_{3} \mathrm{COONa}}
\end{gathered}
$$

$[\mathrm{P}]$ - polymeric sceleton of cation exchanger.

Three types of materials were synthesized: with the functional groups in the $\mathrm{Na}^{+}$form $(\mathrm{M} / \mathrm{Na} \# \mathrm{CuO}, \mathrm{G} / \mathrm{Na} \# \mathrm{CuO})$, with the functional groups in the $\mathrm{Cu}^{2+}$ form $(\mathrm{M} / \mathrm{Cu} \# \mathrm{CuO}$, $\mathrm{G} / \mathrm{Cu} \mathrm{CuO})$, and with the functional groups in the $\mathrm{H}^{+}$form $(\mathrm{M} / \mathrm{H \# CuO}, \mathrm{G} / \mathrm{H \# CuO})$. As the functional groups of both host materials occurred in the $\mathrm{H}^{+}$form $(\mathrm{M} / \mathrm{H}, \mathrm{G} / \mathrm{H})$, consequently, they cannot remove $\mathrm{Cu}^{2+}$ ions from solutions of mineral acid salts (because the acid produced lowers the $\mathrm{pH}$ and prevents further ion exchange); firstly, they had to be converted into the $\mathrm{Na}^{+}$form. For this purpose, $1 \mathrm{M} \mathrm{NaOH}$ was used, initially in the batch method and then in the column, as the reaction (Equation (1)) was running with a thermal effect and with a large increase in the volume of the bed $\left(\mathrm{H}^{+} \rightarrow \mathrm{Na}^{+}\right.$swelling-in-water $80-100 \%$ ). The functional groups in the $\mathrm{Na}^{+}$form could already be converted into the $\mathrm{Cu}^{2+}$ form by passing $0.1 \mathrm{M} \mathrm{CuSO}_{4}$ solution through the resin bed in column (Equation (2)). Then, the resin was shaken with an excess of $\mathrm{NaOH}$ solution in batch condition to precipitate $\mathrm{CuO}$ in its matrix (Equation (3)). To obtain HIX with a simpler elementary composition, the functional groups were converted into the $\mathrm{Cu}^{2+}$ form (Equation (4)). The aim of transformation of $\mathrm{M} / \mathrm{Na} \# \mathrm{CuO}$ and $\mathrm{G} / \mathrm{Na} \# \mathrm{CuO}$ to $\mathrm{M} / \mathrm{H \# CuO}$ and $\mathrm{G} / \mathrm{H \# CuO}$ (Equation (5)) was to obtain HIXs that would not alkalize the reaction environment, as high $\mathrm{pH}$ makes many sorption and catalytic processes inefficient. To perform such gentle transformation effectively, i.e., to prevent the dissolution of the deposit in acidic medium, $0.05 \mathrm{M} \mathrm{CH}_{3} \mathrm{COOH}$ ( $\mathrm{pH} \sim 3.9$ ) was used, considering that the degree of ionization of the $-\mathrm{COOH}$ groups in resins corresponds to that of acetic acid. Therefore, $\mathrm{CH}_{3} \mathrm{COOH}$ solution was passed through the $\mathrm{M} / \mathrm{Na} \# \mathrm{CuO}$ or $\mathrm{G} / \mathrm{Na} \# \mathrm{CuO}$ bed in the column until traces of $\mathrm{Cu}^{2+}$ appeared in the effluent. In the case of $\mathrm{M} / \mathrm{Na} \# \mathrm{CuO}$, this was done at $\mathrm{pH} \sim 6.0$, and in the case of $\mathrm{G} / \mathrm{Na} \# \mathrm{CuO}$ at $\mathrm{pH} \sim 4.7$. This result confirmed the association of the acidity 
of functional groups with the chemical composition of the resin (polymethacrylic acid vs. polyacrylic acid) [58]. At the beginning of the column process, the $\mathrm{pH}$ of the effluent was $\sim 10.5$, due to the presence of $\mathrm{CH}_{3} \mathrm{COONa}$.

Table 2 collects data characterizing reaction products to better interpret their composition. Even though "Cu content in sample" (penultimate column in Table 2) expresses the actual copper content in this sample (per mass unit), these results did not fully reflect the degree of transformation. Practically for each reaction/transformation, the mass of the product differed significantly from the mass of the substrate, not only as a result of chemical reactions but also as a result of different hydration of functional groups depending on their ionic form. Considering the gain/decrease in sample mass, one can estimate that all transformations were carried out virtually quantitatively, and the obtained products contained up to $35 \% \mathrm{wt} \% \mathrm{Cu}$. Figures 1 and 2 (first columns) show photographs of two starting resins and products derived from them.

Table 2. Data of the transformations of carboxylic cation exchangers into HIXs with cupric deposit.

\begin{tabular}{|c|c|c|c|c|c|c|c|c|}
\hline \multirow{2}{*}{ Stage } & \multicolumn{2}{|c|}{ Substrate } & \multicolumn{2}{|c|}{ Product } & \multirow{2}{*}{$\begin{array}{c}\text { Mass } \\
\text { Growth, \% }\end{array}$} & \multicolumn{2}{|c|}{ Cu Content in Sample } & \multirow{2}{*}{$\begin{array}{l}\text { Colour of the } \\
\text { Product }\end{array}$} \\
\hline & Code & Mass, $\mathrm{g}$ & Code & Mass, $\mathrm{g}$ & & meq/g & $\mathrm{mg} / \mathrm{g}$ & \\
\hline \multicolumn{9}{|c|}{ Macroreticular cation exchanger as polymeric support } \\
\hline $\mathrm{A}, \mathrm{B}$ & $\mathrm{M} / \mathrm{H}$ & 9.36 & $\mathrm{M} / \mathrm{Cu}$ & 13.54 & +44.5 & 7.10 & 225.6 & Light blue \\
\hline $\mathrm{C}$ & $\mathrm{M} / \mathrm{Cu}$ & 10.01 & $\mathrm{M} / \mathrm{Na \# CuO}$ & 11.85 & +18.2 & 5.07 & 161.0 & Dark grey \\
\hline $\mathrm{D}$ & $\mathrm{M} / \mathrm{Na} \# \mathrm{CuO}$ & 4.08 & $\mathrm{M} / \mathrm{Cu} \# \mathrm{CuO}$ & 4.26 & +4.4 & 10.30 & 327.3 & Grey blue \\
\hline $\mathrm{E}$ & $\mathrm{M} / \mathrm{Na \# CuO}$ & 4.03 & $\mathrm{M} / \mathrm{H \# CuO}$ & 3.10 & -23.1 & 6.15 & 195.4 & Grey \\
\hline \multicolumn{9}{|c|}{ Gel-like cation exchanger as polymeric support } \\
\hline $\mathrm{A}, \mathrm{B}$ & $\mathrm{G} / \mathrm{H}$ & 9.42 & $\mathrm{G} / \mathrm{Cu}$ & 13.71 & +45.5 & 7.21 & 228.9 & Dark green \\
\hline C & $\mathrm{G} / \mathrm{Cu}$ & 10.35 & $\mathrm{G} / \mathrm{Na} \# \mathrm{CuO}$ & 12.52 & +20.1 & 5.76 & 182.9 & Black \\
\hline $\mathrm{D}$ & $\mathrm{G} / \mathrm{Na \# CuO}$ & 4.31 & $\mathrm{G} / \mathrm{Cu} \mathrm{CuO}$ & 4.49 & +4.17 & 11.16 & 354.4 & Black \\
\hline $\mathrm{E}$ & $\mathrm{G} / \mathrm{Na} \# \mathrm{CuO}$ & 4.17 & $\mathrm{G} / \mathrm{H} \# \mathrm{CuO}$ & 3.22 & -22.8 & 7.35 & 233.3 & Black \\
\hline
\end{tabular}

\subsection{Thermal Analysis in Air}

In order to achieve the second objective of the work, to assess the effect of copper (II) on the thermal decomposition of examined resins and to identify the solid decomposition products, materials with a homogeneous elementary composition, containing copper atoms (not sodium), were selected for analysis. Eight materials-two starting cation exchangers $(\mathrm{M} / \mathrm{H}, \mathrm{G} / \mathrm{H})$, two cation exchangers in the $\mathrm{Cu}^{2+}$ form $(\mathrm{M} / \mathrm{Cu}, \mathrm{G} / \mathrm{Cu})$, two cation exchanger in the $\mathrm{Cu}^{2+}$ form with a $\mathrm{CuO}$ deposit $(\mathrm{M} / \mathrm{Cu} \mathrm{CuO}, \mathrm{G} / \mathrm{Cu} \mathrm{CuO})$, and two cation exchanger in the $\mathrm{H}^{+}$form with a $\mathrm{CuO}$ deposit $(\mathrm{M} / \mathrm{H} \# \mathrm{CuO}, \mathrm{G} / \mathrm{H \# CuO}$ )-were subjected to thermal analysis. The results are grouped according to the structure of the polymeric support (macroreticular or gel-like) and the medium in which the process proceeded (air or $\mathrm{N}_{2}$ ). TG/DTG curves of sixteen experiments with numerical data characterizing the particular transformation, their temperature range, and the temperature at which the maximum decomposition rate, end temperature, mass change, and residual mass occurred are presented. These findings give an opportunity to analyze such phenomena as the effect of the ionic form of the carboxylic groups on the water content of the material. 


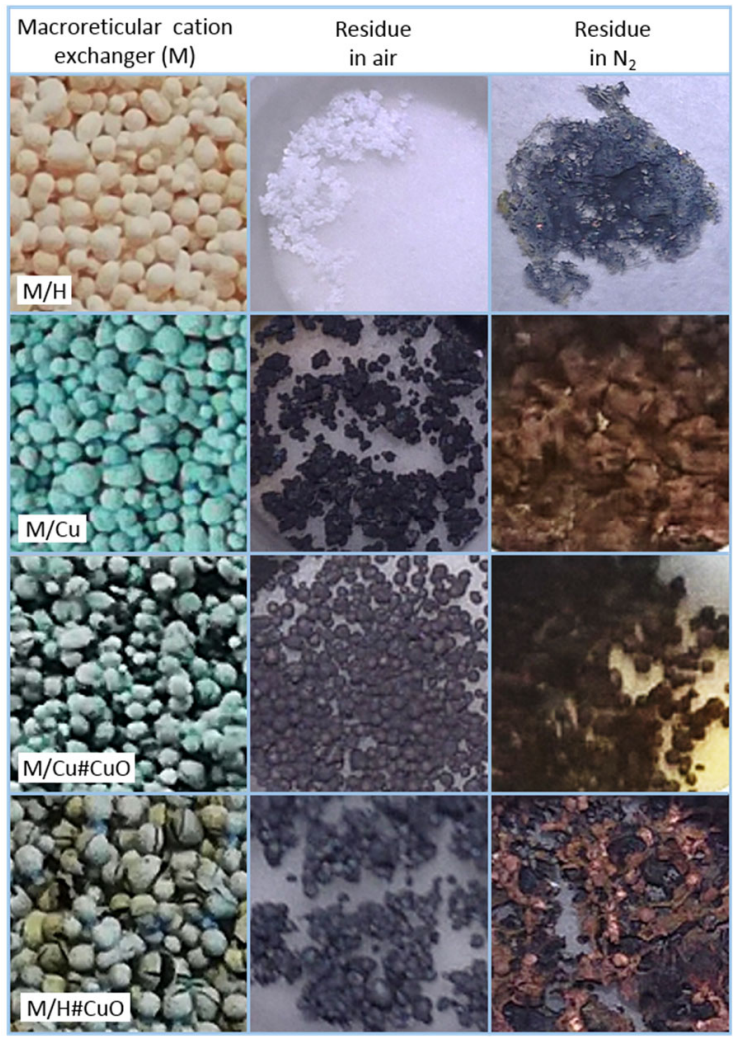

Figure 1. Photographs of examined materials based on macroporous carboxylic cation exchanger (left column), solid residues after their thermal analysis in air (middle column) and in $\mathrm{N}_{2}$ (right column).

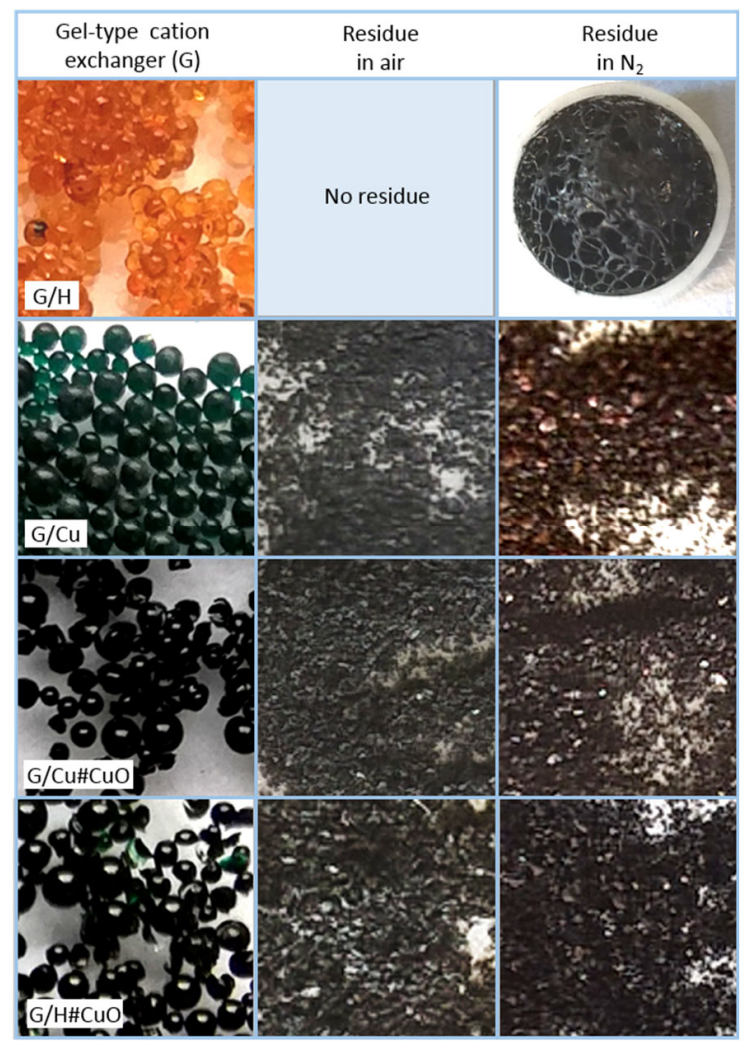

Figure 2. Photographs of examined materials based on gel-type carboxylic cation exchanger (left column), solid residues after their thermal analysis in air (middle column) and in $\mathrm{N}_{2}$ (right column). 
Figure 3a shows the TG/DTG curves recorded in air atmosphere for $\mathrm{M} / \mathrm{H}$, in which the existence of four decomposition steps associated with mass losses can be observed. The first decomposition step up to $132.8^{\circ} \mathrm{C}$ (maximum decomposition rate at $78.4{ }^{\circ} \mathrm{C}$ ) with a mass loss of $4.0 \%$ corresponds to the elimination of osmotic water molecules existing in the pores of resin and hydrogen-bonded water (from hydration sites of carboxylic groups). Compared to the ion exchangers of various type $[40,41,59,60]$, this result is very low and indicates that CCE in the $\mathrm{H}^{+}$form is especially weakly hydrated. The second step up to $282.1^{\circ} \mathrm{C}$ (maximum decomposition rate at $237.8^{\circ} \mathrm{C}$ ) with a mass loss of $11.1 \%$ can be assigned to the water elimination between two neighboring carboxylic groups with the creation of some polyacrylic cyclic anhydrides by intermolecular dehydration (5-atom ring such as succinic anhydride type or 6-atom ring such as glutaric anhydride type, Scheme 2). The third step up to $446.2{ }^{\circ} \mathrm{C}$ (maximum decomposition rate as much as $16.8 \% / \mathrm{min}$ at $416.2{ }^{\circ} \mathrm{C}$ ) with a mass loss of $58.4 \%$ is the most intense transformation in this experiment, and this is a decarboxylation process of the previously dehydrated structure (polyanhydride decomposition through decarboxylation and elimination of $\mathrm{CO}_{2}$ and CO) [61-65]. The last decomposition step up to $503.8^{\circ} \mathrm{C}$ corresponded to the oxidative degradation (combustion) of polymeric matrix when oxygen ( $20.8 \%$ volume) interacts with the hydrocarbon chain and its degradation products. The residue left at $900{ }^{\circ} \mathrm{C}$ is ash and is about $0.9 \%$ of the original sample. The described transformations due to the accompanying changes and mass losses corresponded well to the results described in the work [62], where by mass spectrometry, volatile process products were identified, and FTIR analysis confirmed the formation of polymeric anhydrides as intermediate products of CCE thermal decomposition.

The TG/DTG curves of $\mathrm{M} / \mathrm{Cu}, \mathrm{M} / \mathrm{Cu} \# \mathrm{CuO}$, and $\mathrm{M} / \mathrm{H \# CuO}$ in air (Figure 3b-d) have a similar course but are significantly different in comparison to the parent resin (Figure 3a). When analyzing the data from these three experiments, it should be taken into account that although organic matter in them dominates, it represents no more than $75 \%$ of their mass (and in one case only 60\%). For this reason, the mass loss for the particular stages is smaller than in the case of the parent resin. Analyzing the first transformation corresponding to the evaporation of water molecules, one can see that the samples in which the functional groups in the $\mathrm{Cu}^{2+}$ form are much more hydrated (a greater mass loss is observed on the TG curve) than the samples containing the functional groups in the $\mathrm{H}^{+}$ form. In each experiment, the presence of copper in the tested material, as $\mathrm{Cu}^{2+}$ ions in functional groups and as $\mathrm{CuO}$ particles in the resin matrix, significantly accelerated the thermal decomposition of the host material. The decomposition of these samples ended at a temperature $100{ }^{\circ} \mathrm{C}$ lower than that of $\mathrm{M} / \mathrm{H}$ alone. The significant acceleration of thermal decomposition can be observed in a temperature range of $200-300{ }^{\circ} \mathrm{C}$, where there are two broad peaks indicating intense decomposition of functional groups, and especially very fast decarboxylation (at a temperature of about $150{ }^{\circ} \mathrm{C}$ lower than pure resin). All residues left at about $900{ }^{\circ} \mathrm{C}$ had a mass slightly higher than the copper content in the output sample. In the case of the sample containing the most copper $(\mathrm{M} / \mathrm{Cu} \# \mathrm{CuO}, 32.7 \mathrm{wt} \% \mathrm{Cu})$, the residue represented about $39.2 \mathrm{wt} \%$ of the original sample.

Figure 4 shows the results of similar studies in air, in which as support for copper(II), the gel-like cation exchanger was used. According to Figure $4 \mathrm{a}$, dehydration of $\mathrm{G} / \mathrm{H}$ (maximum decomposition rate at $175.5^{\circ} \mathrm{C}$ with a mass loss of $6.0 \%$ ) was proceeding at a higher temperature than dehydration of $\mathrm{M} / \mathrm{H}$ (maximum decomposition rate at $78.4{ }^{\circ} \mathrm{C}$, Figure 3a). Again, it turned out that the resin in the $\mathrm{H}^{+}$form contained little water, and the compact structure of the gel matrix without real pores (strongly shrinking during drying) made it difficult for water molecules to escape outside [39]. A significant difference in the thermal decomposition of $\mathrm{G} / \mathrm{H}$ compared to $\mathrm{M} / \mathrm{H}$ was observed at $200-300{ }^{\circ} \mathrm{C}$. A mass loss of as much as $21.0 \%$ (maximum decomposition rate at $285.0{ }^{\circ} \mathrm{C}$ ) indicated that for $\mathrm{G} / \mathrm{H}$, the changes taking place went beyond water elimination between two neighboring carboxylic groups with the creation of some polyacrylic cyclic anhydrides by intramolecular dehydration, as in the case of $\mathrm{M} / \mathrm{H}$. The intermolecular dehydration probability with the 
isobutyric anhydride formation (Scheme 2) resulted from the compact structure of the dry gel matrix and the proximity of polymer chains $[62,64,65]$.

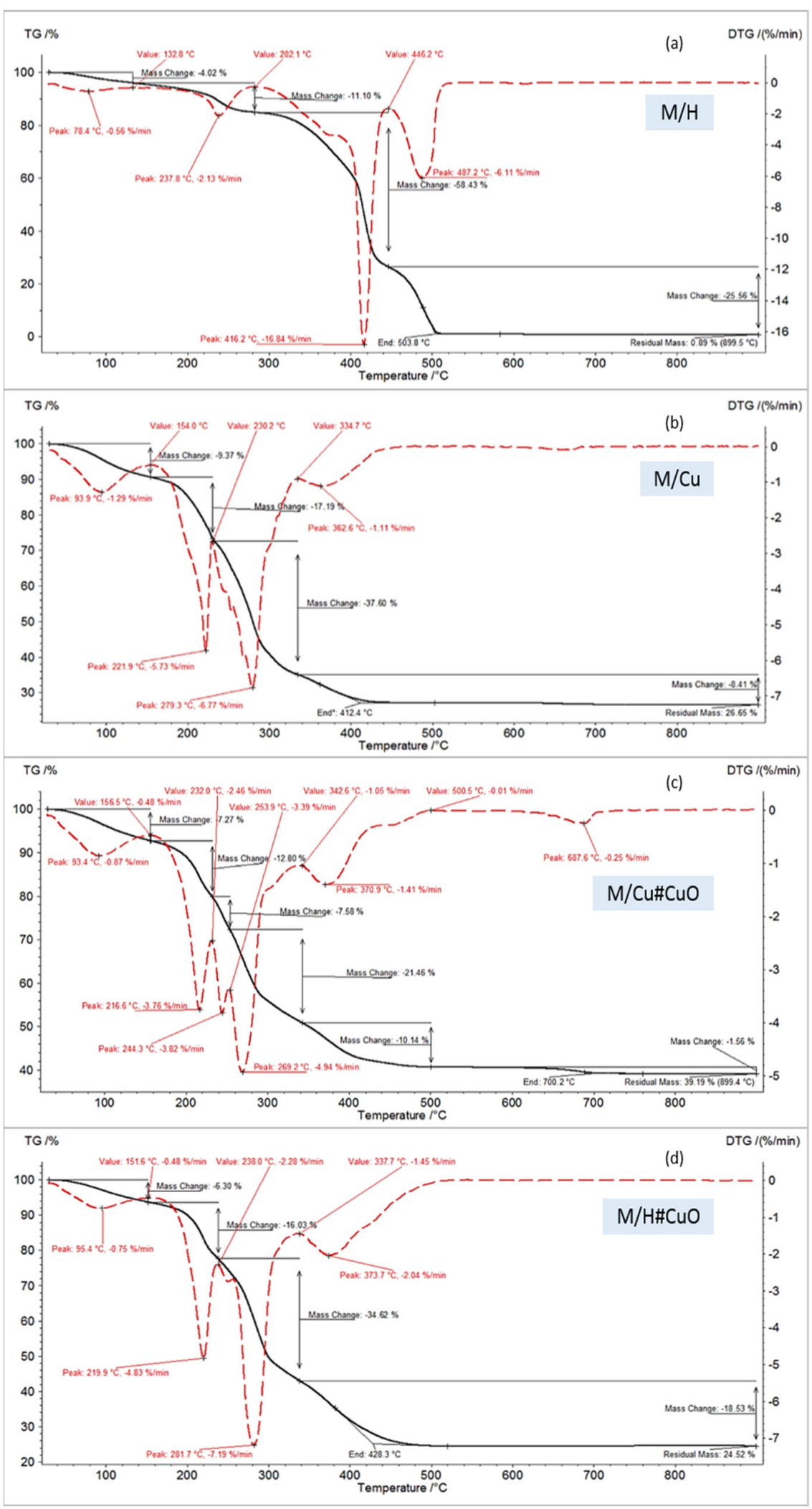

Figure 3. TG/DTG curves in air of (a) $\mathrm{M} / \mathrm{H}$, (b) $\mathrm{M} / \mathrm{Cu}$, (c) $\mathrm{M} / \mathrm{Cu} \# \mathrm{CuO}$, and (d) $\mathrm{M} / \mathrm{H \# CuO}$. 
Poly (acrylic acid - co - divinyl benzene)

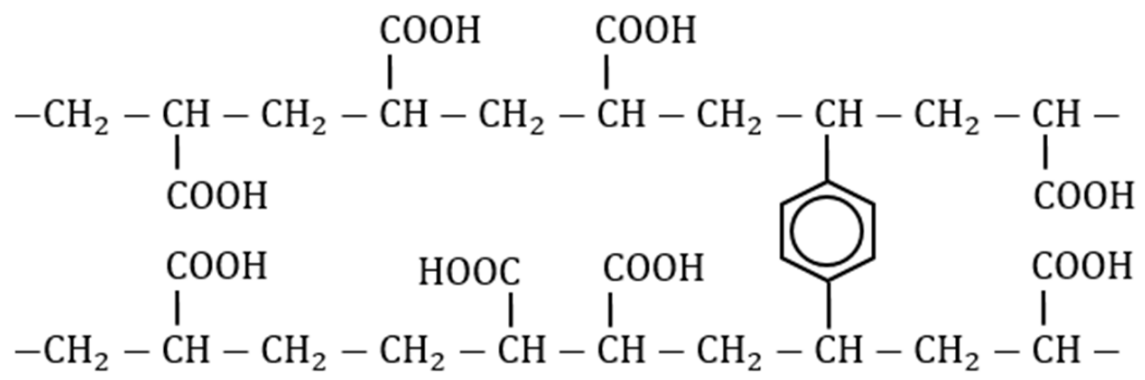

\section{Formation of anhydrides}

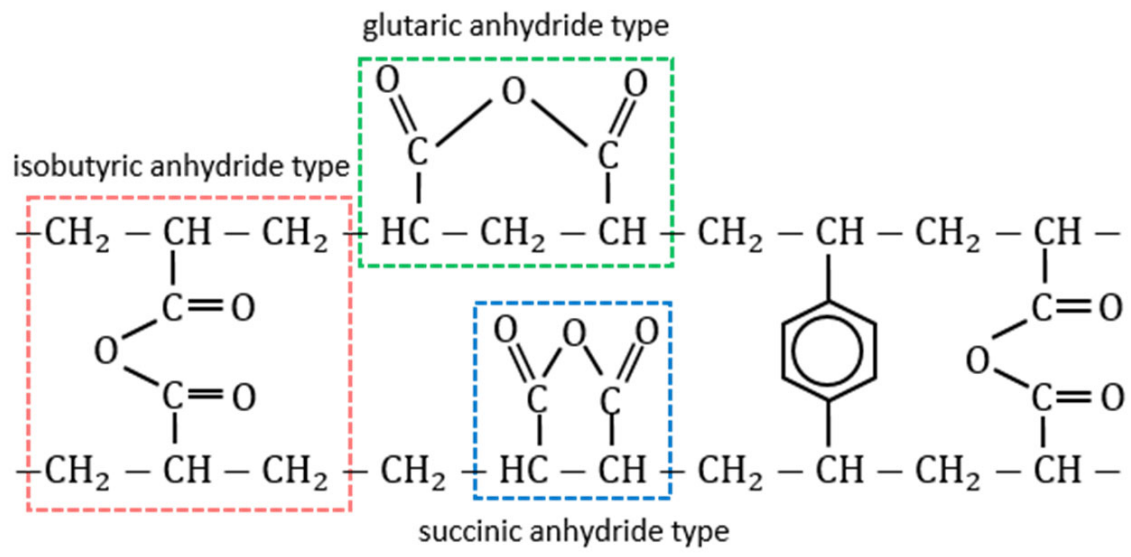

Scheme 2. Formation of anhydrides during thermal decomposition of carboxylic cation exchangers.

The second columns in Figure 1 and in Figure 2 show the residues after thermal decomposition in air. Residues in Figure 2 do not have the shape of beads, as is the case in Figure 1. Studies on the thermal decomposition of three copper-containing samples obtained with gel-like resin gave an unexpected result: during heating, the balls "clicked" and "jumped" out of the crucible, making the resulting TG/DTG curves uninterpretable. Three samples were therefore thermally analyzed after grinding in an agate mortar (Figure $4 \mathrm{~b}-\mathrm{d}$ ). Again, the thermal decomposition of materials containing $\mathrm{Cu}$ (II) occurred much more easily (at a lower temperature) than the thermal decomposition of the host material (end temperature respectively $464.5,427.7$, and $440.1^{\circ} \mathrm{C}$ vs. $551.7^{\circ} \mathrm{C}$ ). For the gel-like host material, the copper contained in it accelerated the decarboxylation step by almost $150{ }^{\circ} \mathrm{C}$ ( $\mathrm{G} / \mathrm{Cu} \# \mathrm{CuO}$ maximum decomposition rate at $276.4^{\circ} \mathrm{C}$, vs. $\mathrm{G} / \mathrm{H}$ at $427.1^{\circ} \mathrm{C}$ ).

The results of thermal decomposition of eight samples in air are presented in Table 3. From data showing the peak temperatures and end temperature of polymer degradation, it can be noted that, in any case, the presence of copper in the sample $\left(\mathrm{as} \mathrm{Cu}^{2+}\right.$ ion or $\mathrm{CuO}$ deposit) shifted the polymeric matter decomposition toward lower temperatures. Due to the high copper content of the test samples, the mass of the combustion residues was also high. An XRD analysis (Figure 5) showed $\mathrm{CuO}$ to be present in the products of the combustion of all the samples. The set of reflections at $2 \theta=32.68,35.73,38.89,48.91,53.70$, $58.29,61.71,66.04$, and 68.25 was consistent with ICSD Card No. 16025. In the G/Cu\#CuO sample, the residue was as much as $49.3 \mathrm{wt} \%$, indicating that polymeric matter (a phase susceptible to thermal decomposition) represented only half of the initial sample. 


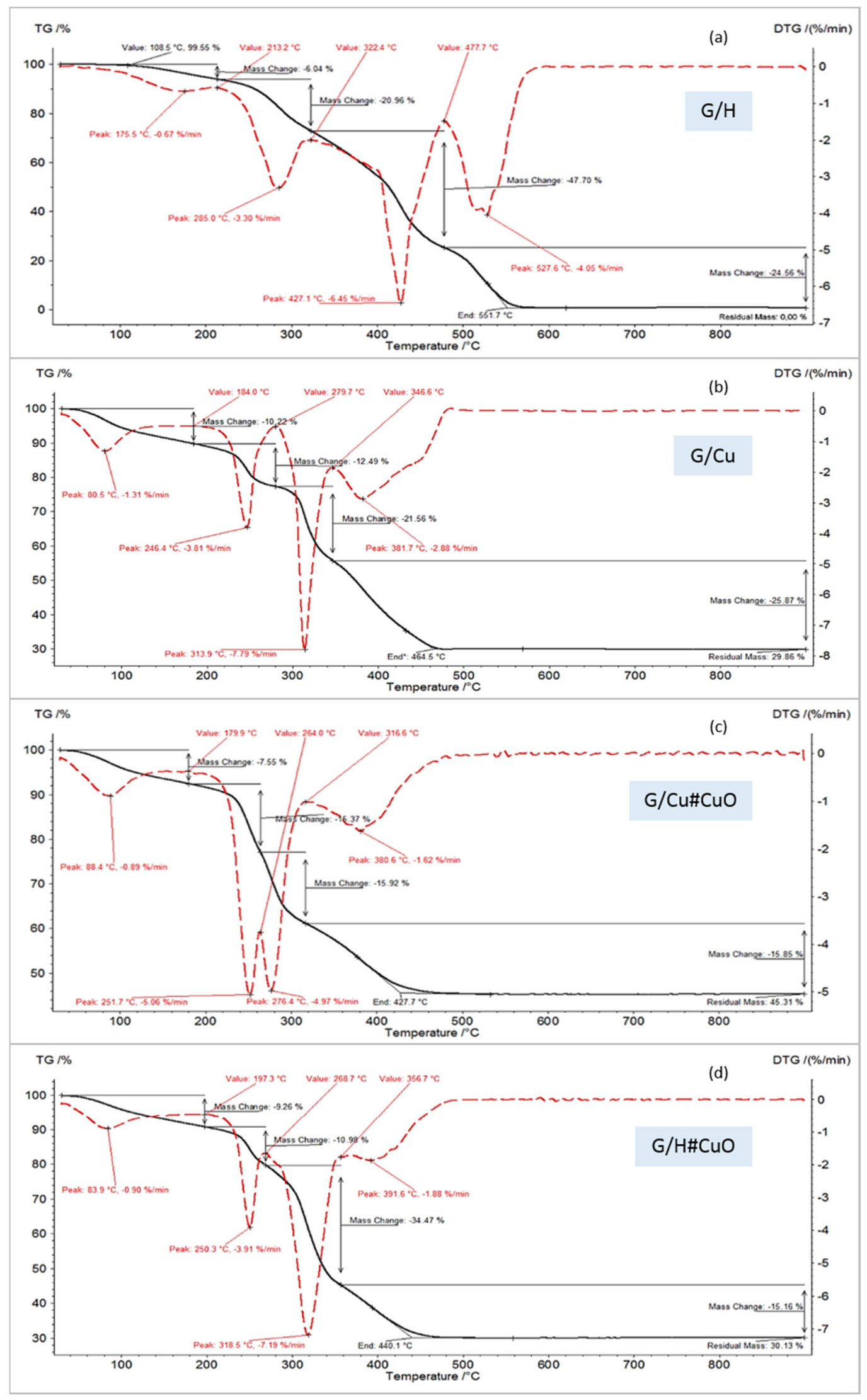

Figure 4. TG/DTG curves in air of (a) G/H, (b) G/Cu, (c) G/Cu\#CuO, and (d) G/H\#CuO. 
Table 3. Thermal decomposition results.

\begin{tabular}{|c|c|c|c|c|}
\hline Code & Water Mass Loss, \% & $\begin{array}{c}\text { Peak Temperature of Polymer } \\
\text { Degradation, }{ }^{\circ} \mathrm{C}\end{array}$ & End Temperature, ${ }^{\circ} \mathrm{C}$ & Residual Mass, $\%$ \\
\hline \multicolumn{5}{|c|}{ decomposition in air } \\
\hline $\mathrm{M} / \mathrm{H}$ & 4.02 & $237.8,416.2,487.2$ & 503.8 & 0.89 \\
\hline $\mathrm{M} / \mathrm{Cu}$ & 9.37 & $221.9,279.3,362.6$ & 412.4 & 26.65 \\
\hline $\mathrm{M} / \mathrm{Cu} \mathrm{AuO}$ & 7.27 & $216.6,269.2370 .9$ & 420.0 & 39.19 \\
\hline M/H\#CuO & 6.30 & $219.9,281.7,373.7$ & 428.3 & 24.52 \\
\hline $\mathrm{G} / \mathrm{H}$ & 6.04 & $285.0,427.1,527.6$ & 551.7 & 0 \\
\hline $\mathrm{G} / \mathrm{Cu}$ & 10.22 & $246.4,313.9,381.7$ & 464.5 & 29.86 \\
\hline G/Cu\#CuO & 7.55 & $251.7,276.4,380.6$ & 427.7 & 46.31 \\
\hline $\mathrm{G} / \mathrm{H} \# \mathrm{CuO}$ & 9.26 & $250.3,318.5,391.6$ & 440.1 & 30.13 \\
\hline \multicolumn{5}{|c|}{ decomposition in $\mathrm{N}_{2}$} \\
\hline $\mathrm{M} / \mathrm{H}$ & 4.73 & $238.8,429.5$ & 440.4 & 6.10 \\
\hline $\mathrm{M} / \mathrm{Cu}$ & 9.28 & $203.5,302.2,369.3$ & 446.2 & 27.43 \\
\hline $\mathrm{M} / \mathrm{Cu} \# \mathrm{CuO}$ & 7.14 & $213.4,251.3,290.7,392.2$ & 448.7 & 40.98 \\
\hline $\mathrm{M} / \mathrm{H \# CuO}$ & 6.27 & 220.7. $296.2,403.5$ & 434.0 & 27.67 \\
\hline $\mathrm{G} / \mathrm{H}$ & 5.74 & $284.6,442.8$ & 459.5 & 12.17 \\
\hline $\mathrm{G} / \mathrm{Cu}$ & 9.18 & $246.2,317.4,409.2$ & 442.1 & 40.27 \\
\hline $\mathrm{G} / \mathrm{Cu} \# \mathrm{CuO}$ & 6.70 & $251.5,289.8,423.4$ & 456.4 & 49.30 \\
\hline $\mathrm{G} / \mathrm{H} \# \mathrm{CuO}$ & 8.08 & $249.7,334.9,420.7$ & 450.5 & 40.11 \\
\hline
\end{tabular}

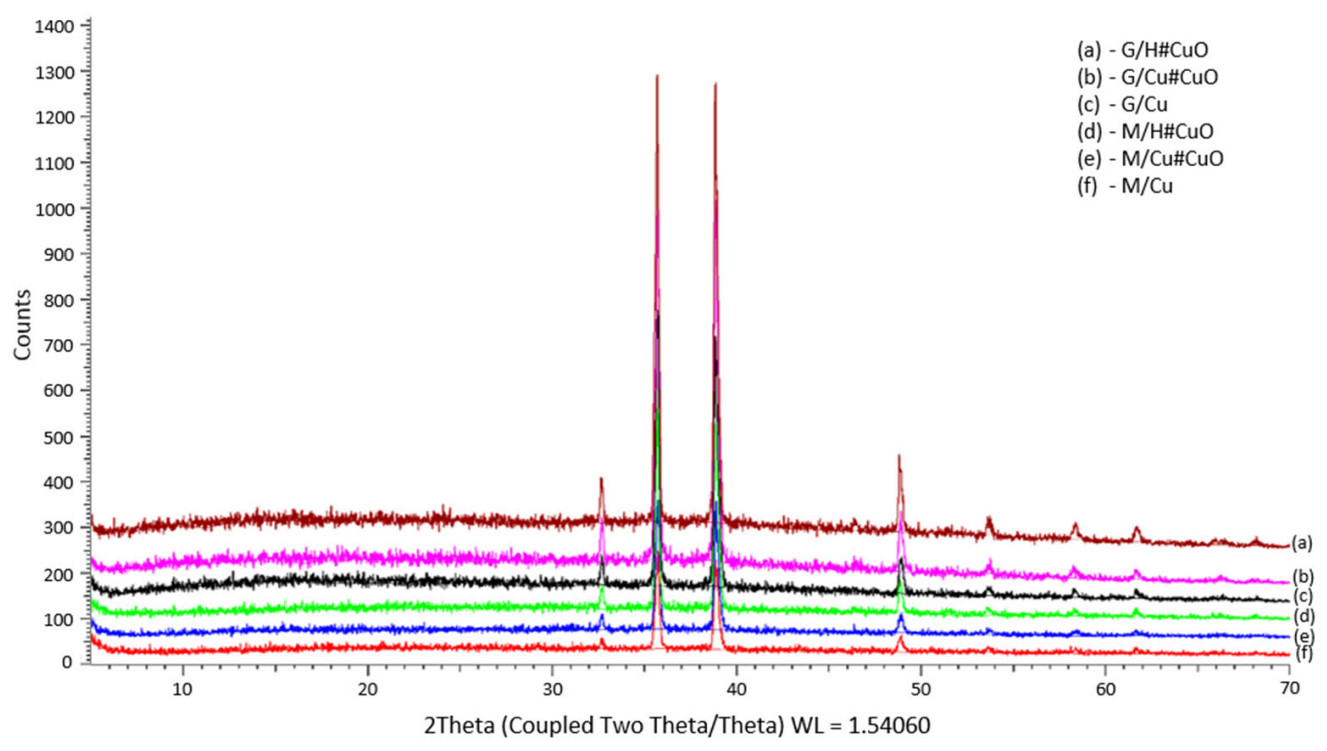

Figure 5. XRD patterns of residues in air.

At the end of the studies carried out in air atmosphere, it is necessary to comment on the effect that the physical form of the sample has on the results of thermal analysis. When carrying out comparative tests for samples of the $\mathrm{M}$ series that could be analyzed as grinded or granulated, no significant differences were found in the course of TG/DTG curves. In the next series of tests (under $\mathrm{N}_{2}$ ), the samples were in the same physical form as under air. 


\subsection{Thermal Analysis in Nitrogen}

Figures 6 and 7 show TG/DTG curves of the same eight samples but recorded in $\mathrm{N}_{2}$ atmosphere. Up to $400{ }^{\circ} \mathrm{C}$, both pure resins $(\mathrm{M} / \mathrm{H}, \mathrm{G} / \mathrm{H})$ decomposed just like in air (Figures $6 \mathrm{a}$ and $7 \mathrm{a}$ vs. Figures $3 \mathrm{a}$ and $4 \mathrm{a}$ ). However, at about $400{ }^{\circ} \mathrm{C}$, there was only one intensive transformation in $\mathrm{N}_{2}$ (in air there were two separate transformations), including decarboxylation and decomposition of the polymeric matrix (loss in mass $71.0 \mathrm{wt} \%$ for $\mathrm{M} / \mathrm{H}$ and $62.0 \mathrm{wt} \%$ for $\mathrm{G} / \mathrm{H}$ ). For $\mathrm{M} / \mathrm{H}$ and $\mathrm{G} / \mathrm{H}$, the end temperature in $\mathrm{N}_{2}$ was significantly lower than in air. The solid residue from $\mathrm{M} / \mathrm{H}$ pyrolysis accounted for approximately $6.0 \mathrm{wt} \%$. The solid residue from $\mathrm{G} / \mathrm{H}$ pyrolysis $(12.0 \mathrm{wt} \%)$ had an unusual form of foam/sponge, which "tried to get out" of the crucible (Figure 2, last column). As one can see in Figures $6 \mathrm{~b}-\mathrm{d}$ and $7 \mathrm{~b}-\mathrm{d}$, all HIXs in $\mathrm{N}_{2}$ decomposed in four stages (as in air); they decomposed much faster than the reference material (pure resin) and slightly slower (at a slightly higher temperature) than in air.

The interesting issues of the pyrolysis of six HIXs are connected with the composition and amount of the solid residue (pyrolysate). The pyrolysate has a much larger mass than the ash (the post-combustion residue) since, besides a mineral phase, it contains an organic phase (carbon char). More precisely, the pyrolysate contains carbon char (a mixture of various high molecular weight organic compounds constituting a product of the decomposition of the polymer's matrix in air-free conditions) and inorganic matter (mainly deriving from the cupric deposit). Our previous study showed that during pyrolysis, the particles of copper compounds such $\mathrm{CuO}, \mathrm{Cu}(\mathrm{OH})_{2}$, and $\mathrm{Cu}_{2} \mathrm{O}$ contained in the HIX received from anion exchangers had undergone reduction to $\mathrm{Cu}^{0}[40,41]$. Although, in this case, the mass of cupric deposit in the skeleton was several times greater, the result was the same. Figure 8 shows six XRD patterns revealing that the inorganic load consisted of metallic copper (peaks at $2 \theta=43.44$ and 50.57, ICSD Card No. 43493). This is a valuable result as it means that, during pyrolysis, the whole of $\mathrm{Cu}$ (II) in CCE has been reduced to metallic copper (not to a mixture of copper compounds at different oxidation levels), for which a large amount of reducer (above $10.0 \mathrm{meq} / \mathrm{g}$ ) was needed. In the photographs of pyrolysates (Figures 1 and 2, last column), the characteristic color of metallic copper can be seen.

The pyrolysates obtained during this study stand out in terms of mass and chemical composition. For the first time, we obtained pyrolysates with mass that represented as much as $50 \mathrm{wt} \%$ of the initial sample. For the first time, we obtained pyrolysates in which the inorganic phase (which was metallic copper) dominated. The high content of metallic copper in pyrolysate was due to the high $\mathrm{Cu}$ (II) content in the material subjected to pyrolysis and the process conditions for quantitative reduction. Comparing "solid residue" and " $\mathrm{Cu}$ content in respective starting sample" (Tables 2 and 3), it can be estimated that $\mathrm{HIX} / \mathrm{M}$ pyrolysates contained $70-80 \% \mathrm{wt} \% \mathrm{Cu}$ and HIX/G pyrolysates $60-70 \% \mathrm{wt} \% \mathrm{Cu}$. As in the previous research $[40,41,60]$, it turned out again that under $\mathrm{N}_{2}$, more pyrolysate formed from HIXs than in the case of the same transformation of pure resins (M, G). The research presented here shows that the polymeric matter from which the carboxylic cation exchanger is made (in addition to carbon and hydrogen atoms containing oxygen atoms) during pyrolysis does not give as much carbon char as in the case of a hydrocarbonaceous (oxygen-free) polystyrene matrix of anion exchange resin. However, there is no doubt that during pyrolysis of the polyacrylic/polymethacrylic matrix, the products of its decomposition (free radicals and hydrogen) participate in creation of an additional amount of carbon char due to the consumption of a certain amount of hydrogen to reduce $\mathrm{Cu}$ (II) to $\mathrm{Cu}^{0}$. The data show that as a result of pyrolysis, HIXs richest in copper $(\mathrm{M} / \mathrm{Cu} \# \mathrm{CuO}$ and $\mathrm{G} / \mathrm{Cu} \mathrm{AuO}$ ) formed approximately $100 \%$ more carbon char than during pyrolysis of the respective cation exchangers with no copper deposit. Though both CCEs contained as much as $40.0 \mathrm{wt} \%$ oxygen in the macromolecule (the hydrocarbon chain accounted for less than half of the macromolecules), they have proven to be reagents capable of quantitatively reducing cupric deposits. 


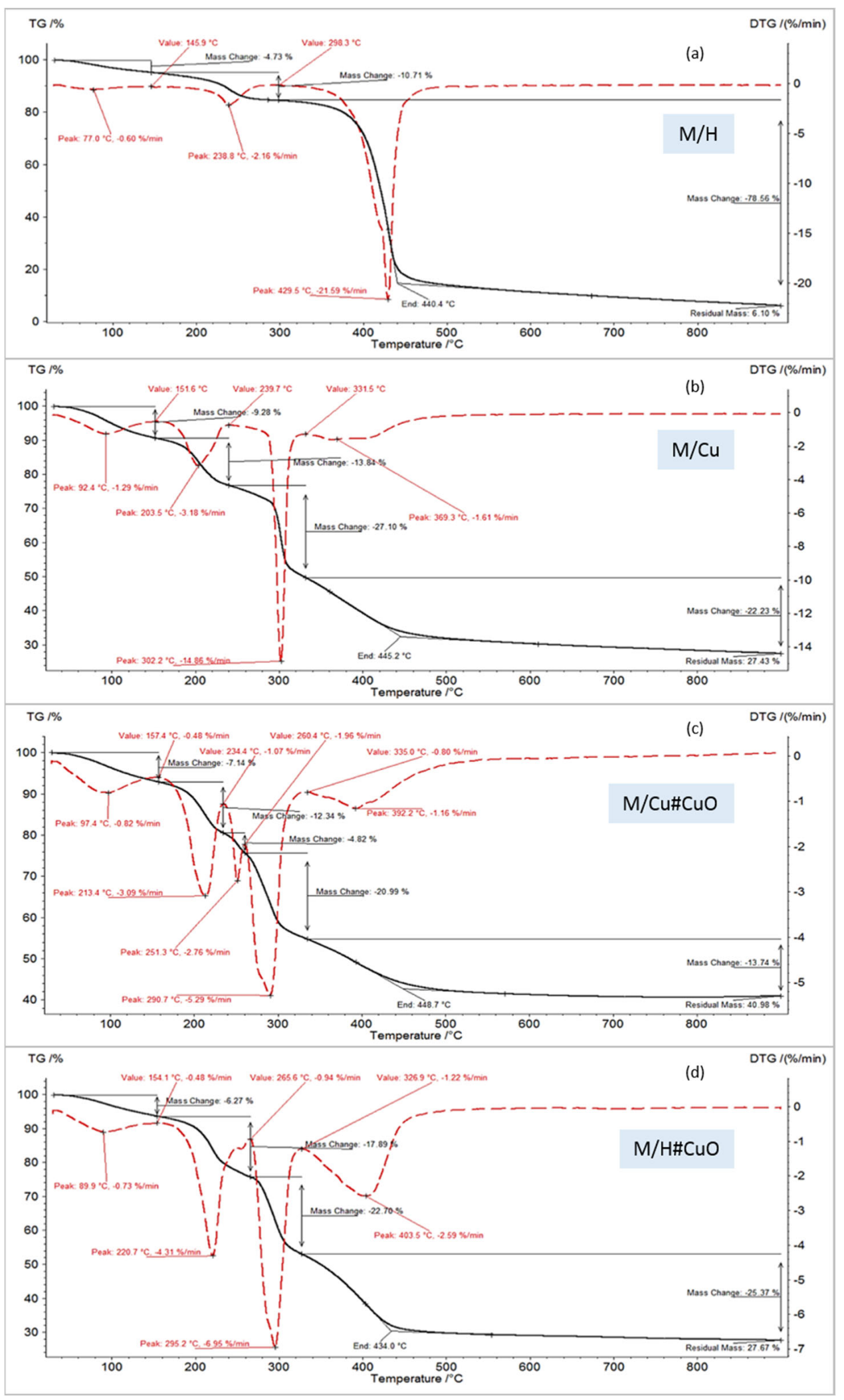

Figure 6. TG/DTG curves in $\mathrm{N}_{2}$ of $(\mathbf{a}) \mathrm{M} / \mathrm{H},(\mathbf{b}) \mathrm{M} / \mathrm{Cu}$, (c) $\mathrm{M} / \mathrm{Cu} \# \mathrm{CuO}$, and (d) $\mathrm{M} / \mathrm{H \# CuO}$. 


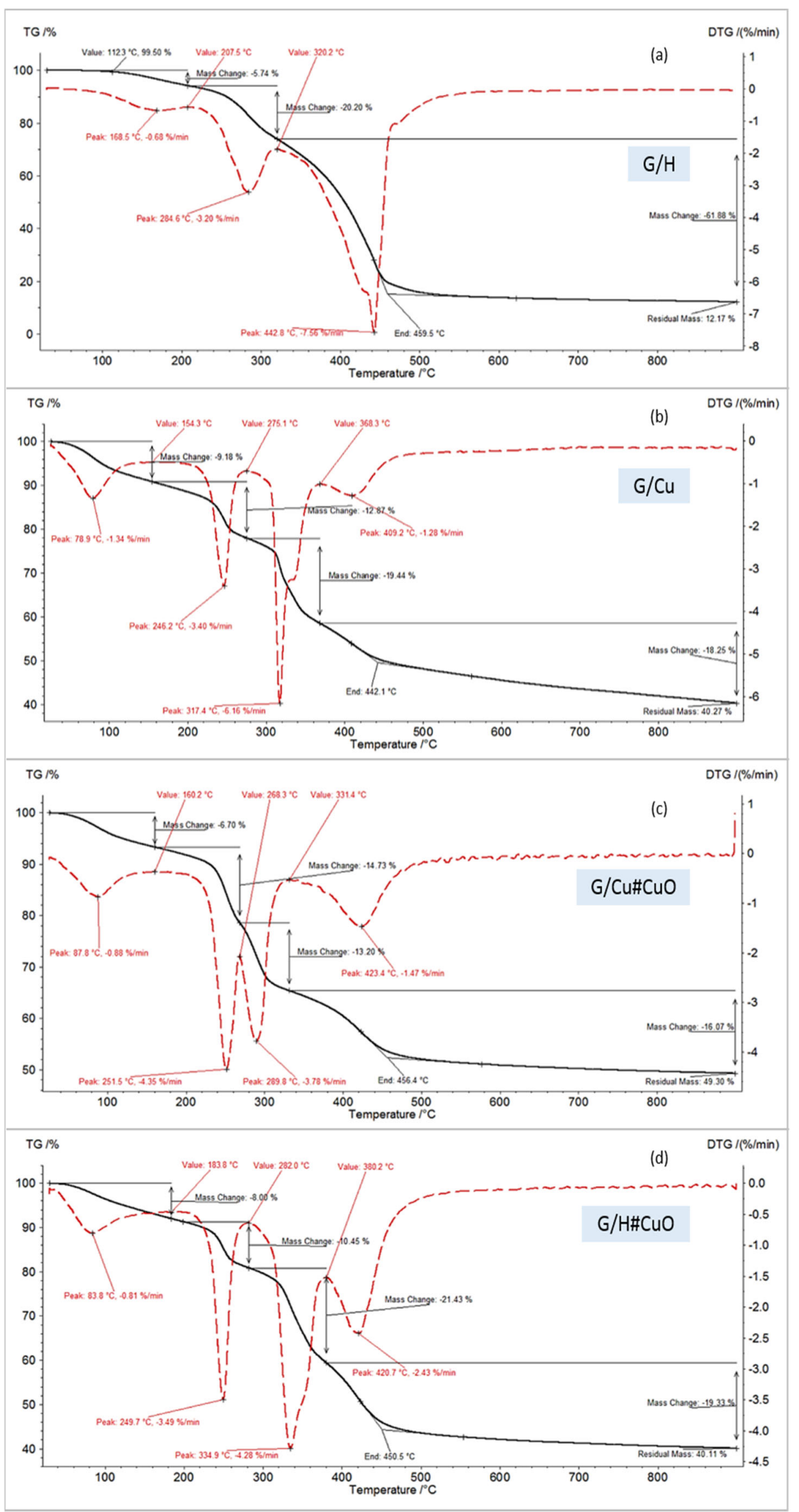

Figure 7. TG/DTG curves in $\mathrm{N}_{2}$ of (a) $\mathrm{G} / \mathrm{H},(\mathbf{b}) \mathrm{G} / \mathrm{Cu}$, (c) $\mathrm{G} / \mathrm{Cu} \# \mathrm{CuO}$, and (d) $\mathrm{G} / \mathrm{H} \# \mathrm{CuO}$. 


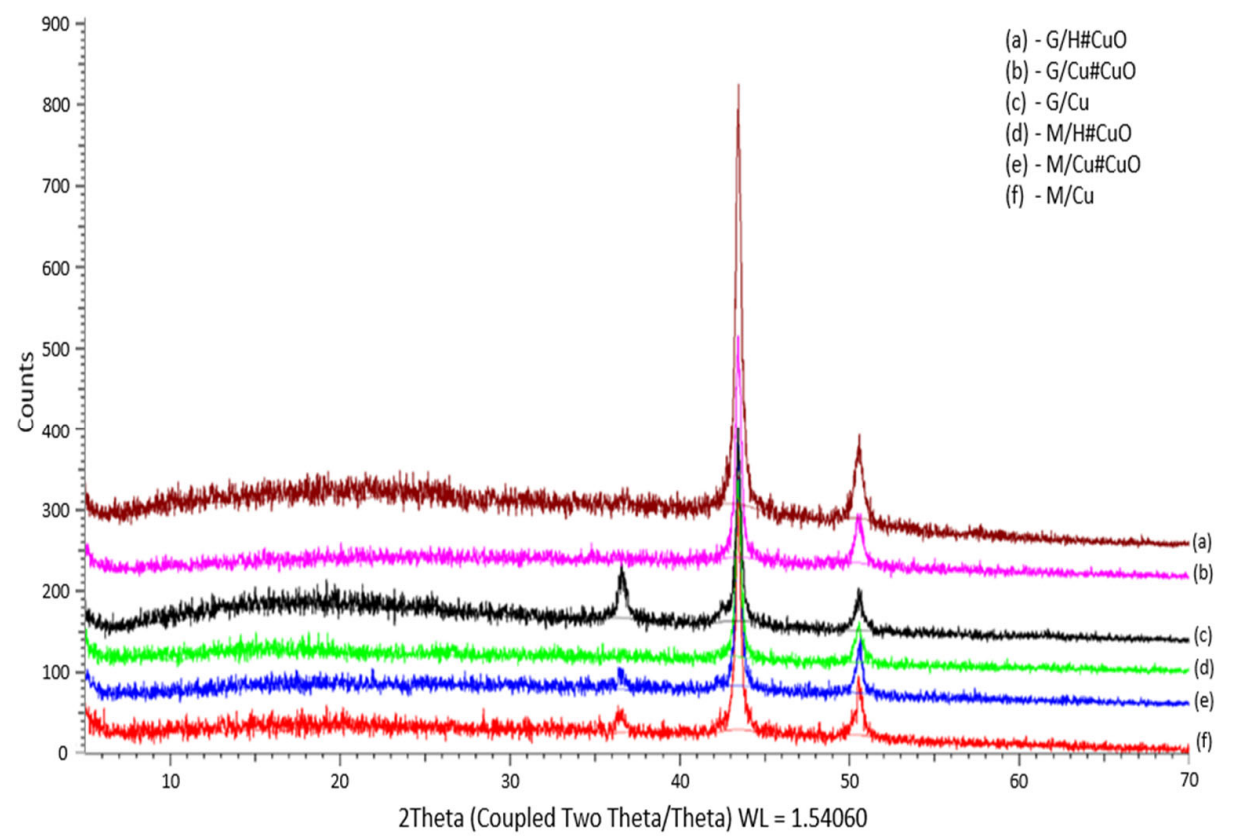

Figure 8. XRD patterns of residues in $\mathrm{N}_{2}$.

\section{Conclusions}

Carboxylic cation exchangers with very high ion exchange capacity can be used as host materials for receiving copper-rich hybrid ion exchangers. Using simple transformations in ambient conditions, macroreticular and gel-like HIXs with $\mathrm{CuO}$ particles with up to 195.0 and $233.0 \mathrm{mg} \mathrm{Cu} / \mathrm{g}$ content were obtained. As carboxyl groups in CCEs are weakly acidic, using a dilute acetic acid solution HIXs containing both the $\mathrm{CuO}$ deposit and the functional groups in the $\mathrm{H}^{+}$form can be obtained. HIXs enriched with copper, containing the $\mathrm{CuO}$ deposit and the functional groups in the $\mathrm{Cu}^{2+}$ form, could also be obtained (such materials contained up to $35.0 \mathrm{wt} \% \mathrm{Cu}$ ). All composites (regardless of the ionic form of functional groups) were extremely electrified (attached to paper, "jumped" from the dish).

Samples of both starting materials $(\mathrm{M} / \mathrm{H}$ and $\mathrm{G} / \mathrm{H})$ and also $\mathrm{M} / \mathrm{Cu}, \mathrm{M} / \mathrm{Cu} \# \mathrm{CuO}$, and $\mathrm{M} / \mathrm{H \# CuO}$ can be thermally analyzed in natural form (beads). $\mathrm{G} / \mathrm{Cu}, \mathrm{G} / \mathrm{Cu} \# \mathrm{CuO}$, and $\mathrm{G} / \mathrm{H \# CuO}$ samples were ground before measurement (otherwise they "pop out" from the measuring crucible).

The TG/DTG curves both CCEs and HIXs with the cupric deposit had a peculiar, characteristic course. Carboxyl groups attached to a skeleton with different structures (with polymer chains located close to each other or separated by macropores in the macromolecule) dehydrated/decarboxylated in different ways to intermolecular or intramolecular dehydration.

Under air, the copper deposit significantly accelerated the decomposition of CCEs in such a way that subsequent changes occurred at a lower temperature, and the end temperature of ultimate polymeric matter decomposition was also lower ( $\left.551.7 \mathrm{vs} .427 .7^{\circ} \mathrm{C}\right)$. For CCE in the $\mathrm{Cu}^{2+}$ form and for CCE containing dispersed CuO, the TG/DTG curves had a similar course. Materials with both $\mathrm{Cu}^{2+}$ and $\mathrm{CuO}$ contained the most copper and decomposed the fastest. For all analyses carried out under air, $\mathrm{CuO}$ was the solid residue. Its mass was up to $46.3 \%$.

Under $\mathrm{N}_{2}$, all HIXs decomposed much faster than the reference material (pure resin) and slightly slower (at a slightly higher temperature) than in air. During pyrolysis, pyrolysates were formed with mass that represented as much as $50 \mathrm{wt} \%$ of the sample's starting mass, consisting mainly of the inorganic phase (not organic as is usually the case), which was metallic copper $(60-80 \% \mathrm{Cu})$. The creation of metallic copper was due to the reduced division into the cupric deposit of the products of polymer matrix thermal decomposition (free radicals and hydrogen). Simultaneously, free radicals participated in 
the creation of an additional amount of carbon char due to the consumption of a certain amount of hydrogen to reduce $\mathrm{Cu}$ (II) to $\mathrm{Cu}^{0}$. CCEs, despite their high oxygen content (about $40.0 \mathrm{wt} \%$ ), have proven to be very effective reducers in the pyrolysis process.

Author Contributions: Conceptualization, E.K.-B.; methodology E.S., I.J.-S., and I.M.; software, I.M.; formal analysis I.J.-S. and I.M.; investigation, E.S. and I.M.; resources, E.S.; validation, I.M.; writingoriginal draft preparation, E.K.-B., I.J.-S., and I.M.; writing-review and editing, E.K.-B.; supervision, E.K.-B. All authors have read and agreed to the published version of manuscript.

Funding: This research received no external funding.

Institutional Review Board Statement: Not applicable.

Informed Consent Statement: Not applicable.

Data Availability Statement: The data are available from the corresponding author upon request.

Conflicts of Interest: The authors declare no conflict of interest.

\section{References}

1. Hao, J.; Meng, X.; Fang, S.; Cao, H.; Jv, W.; Zheng, X.; Liu, C.; Chen, M.; Sun, Z. $\mathrm{MnO}_{2}$ functionalized amorphous carbon sorbents from spent lithium-ion batteries for highly efficient removal of cadmium from aqueous solutions. Ind. Eng. Chem. Res. 2020, 59, 10210-10220. [CrossRef]

2. Liu, W.-J.; Jiang, H.; Yu, H.-Q. Development of biochar-based functional materials: Toward a sustainable platform carbon material. Chem. Rev. 2015, 115, 12251-12285. [CrossRef]

3. Li, R.; Wang, J.J.; Gaston, L.A.; Zhou, B.; Li, M.; Xiao, R.; Wang, Q.; Zhang, Z.; Hui, H.; Liang, W.; et al. An overview of carbothermal synthesis of metal-biochar composites for the removal of oxyanion contaminants from aqueous solution. Carbon 2018, 129, 674-687. [CrossRef]

4. Ghosh, B.K.; Hazra, S.; Naik, B.; Nath Ghosh, N.N. Preparation of Cu nanoparticle loaded SBA-15 and their excellent catalytic activity in reduction of variety of dyes. Powder Technol. 2015, 269, 371-378. [CrossRef]

5. Tamayo, L.; Azócar, M.; Kogan, M.; Riveros, A.; Páez, M. Copper-polymer nanocomposites: An excellent and cost-effective biocide for use on antibacterial surfaces. Mater. Sci. Eng. C 2016, 69, 1391-1409. [CrossRef] [PubMed]

6. Ociński, D. Optimization of hybrid polymer preparation by ex situ embedding of waste Fe/Mn oxides into chitosan matrix as an effective As (III) and As(V) sorbent. Environ. Sci. Pollut. Res. 2019, 26, 26026-26038. [CrossRef] [PubMed]

7. Nagarajan, D.; Venkatanarasimhan, S. Copper (II) oxide nanoparticles coated cellulose sponge-An effective heterogeneous catalyst for the reduction of toxic organic dyes. Environ. Sci. Pollut. Res. 2019, 26, 22958-22970. [CrossRef] [PubMed]

8. Liang, G.; Hu, Z.; Wang, Z.; Yang, X.; Xie, X.; Zhao, J. Effective removal of carbamazepine and diclofenac by $\mathrm{CuO} / \mathrm{Cu}{ }_{2} \mathrm{O} / \mathrm{Cu}-$ biochar composite with different adsorption mechanisms. Environ. Sci. Pollut. Res. 2020, 27, 45435-45446. [CrossRef]

9. Mallakpour, S.; Azadi, E.; Hussain, C.M. Environmentally benign production of cupric oxide nanoparticles and various utilization of their polymeric hybrids in different technologies. Coordin. Chem. Rev. 2020, 419, 213378. [CrossRef]

10. Gupta, K.; Joshi, P.; Gusain, R.; Khatri, O.P. Recent advances in adsorptive removal of heavy metal and metalloid ions by metal oxide-based nanomaterials. Coordin. Chem. Rev. 2021, 445, 214100. [CrossRef]

11. SenGupta, A.K. Ion Exchange in Environmental Processes: Fundamentals, Applications and Sustainable Technology; John Wiley \& Sons, Inc.: Hoboken, NJ, USA, 2017; pp. 345-390.

12. Hua, M.; Yang, B.; Shan, C.; Zhang, W.; He, S.; Lv, L.; Pan, B. Simultaneous removal of As(V) and Cr(VI) from water by macroporous anion exchanger supported nanoscale hydrous ferric oxide composite. Chemosphere 2017, 171, 126-133. [CrossRef]

13. Tan, L.; Shuang, C.; Wang, Y.; Wang, J.; Su, Y.; Li, A. Effect of pore structure on the removal of clofibric acid my magnetic anion exchange resin. Chemosphere 2018, 191, 817-824. [CrossRef]

14. Zhao, X.; Zhang, Y.; Pan, S.; Zhang, X.; Zhang, W.; Pan, B. Utilization of gel-type polystyrene host for immobilization of nano-sized hydrate zirconium oxides: A new strategy for enhanced phosphate removal. Chemosphere 2021, 263, 127938. [CrossRef]

15. Bui, T.H.; Hong, S.P.; Kim, C.; Yoon, J. Performance analysis of hydrated Zr (IV) oxide nanoparticle-impregnated anion exchange resin for selective phosphate removal. J. Colloid Interf. Sci. 2021, 586, 741-747. [CrossRef]

16. Jacukowicz-Sobala, I.; Wilk, Ł.J.; Drabent, K.; Kociołek-Balawejder, E. Synthesis and characterization of hybrid materials containing iron oxide for removal of sulfides from water. J. Colloid. Interf. Sci. 2015, 460, 154-163. [CrossRef] [PubMed]

17. Wilk, Ł.J.; Ciechanowska, A.; Kociołek-Balawejder, E. Adsorptive-oxidative removal of sulfides from water by $\mathrm{MnO}_{2}$-loaded carboxylic cation exchangers. Materials 2020, 13, 5124. [CrossRef] [PubMed]

18. Jacukowicz-Sobala, I.; Ociński, D.; Mazur, P.; Stanisławska, E.; Kociołek-Balawejder, E. Cu(II)-Fe(III) oxide doped anion exchangers-Multifunctional composites for arsenite removal from water via As(III) adsorption and oxidation. J. Hazard. Mater. 2020, 394, 122527. [CrossRef] [PubMed]

19. Jacukowicz-Sobala, I.; Kociołek-Balawejder, E.; Stanisławska, E.; Dworniczek, E.; Seniuk, A. Antimicrobial activity of anion exchangers containing cupric compounds against Enterococcus faecalis. Colloid Surf. A 2019, 576, 103-109. [CrossRef] 
20. Li, H.; Shan, C.; Zhang, Y.; Cai, J.; Zhang, W.; Pan, B. Arsenate adsorption by hydrous oxide nanoparticles embedded in cross-linked anion exchanger; effect of the host pore structure. ACS Appl. Mater. Interfaces 2016, 8, 3012-3020. [CrossRef]

21. Juang, R.-S.; Lee, T.-S. Oxidative pyrolysis of organic ion exchange resins in the presence of metal oxide catalysts. J. Hazard. Mater. 2002, 92, 301-314. [CrossRef]

22. Zhang, X.; Liu, M.; Gao, X. The co-combustion and pollutant emission characteristics of the three kinds of waste ion exchange resins and coal. Int. J. Chem. React. Eng. 2020, 18, 20200053. [CrossRef]

23. Kinoshita, K.; Hirata, M.; Yahata, T. Treatment of ion-exchange resins by fluidized bed incinerator equipped with copper oxide catalyst. J. Nucl. Sci. Technol. 1991, 28, 228-238. [CrossRef]

24. Chun, U.-K.; Choi, K.; Yang, K.-H.; Park, J.-K.; Song, M.-J. Waste minimization pretreatment via pyrolysis and oxidative pyrolysis of organic ion exchange resin. Waste Manage. 1998, 18, 183-196. [CrossRef]

25. Wojtaszek, M.; Wasielewski, R. The use of spent ion exchange resins as components of the coal charge for the production of metallurgical coke. Fuel 2021, 286, 119249. [CrossRef]

26. Luca, V.; Bianchi, H.L.; Allevatto, F.; Vaccaro, J.O.; Alvarado, A. Low temperature pyrolysis of simulated spent anion exchange resins. J. Environ. Chem. Eng. 2017, 5, 4165-4172. [CrossRef]

27. Scheithauer, D.; Heschel, W.; Meyer, B.; Krzack, S. Pyrolysis of undoped and multi-element doped ion exchange resins with regard to storage properties. J. Anal. Appl. Pyrol. 2017, 124, 276-284. [CrossRef]

28. You, Y.-W.; Moon, E.-H.; Heo, I.; Park, H.; Hong, J.-S.; Suh, J.-K. Preparation and characterization of porous carbons from ion-exchange resins with different degree of cross-linking for hydrogen storage. J. Ind. Eng. Chem. 2017, 45, 164-170. [CrossRef]

29. Wei, M.; Yu, Q.; Duan, W.; Zuo, Z.; Huo, L.; Dai, J. CO $\mathrm{CO}_{2}$ adsorption and desorption performance of waste ion-exchange resin-based activated carbon. Environ. Prog. Sust. Ener. 2018, 37, 703-711. [CrossRef]

30. Matsumura, T.; Takagi, H.; Tanaike, O.; Sakane, H.; Miyajima, N. Iodine-assisted control of the pore and morphology in the porous carbons prepared by the carbonization of ion-exchange resins. Micropor. Mesopor. Mater. 2019, 282, 237-242. [CrossRef]

31. He, P.; Haw, K.-G.; Yan, S.; Tang, L.; Fang, Q.; Qiu, S.; Valtchev, V. Carbon beads with a well-defined pore structure derived from ion-exchange resin beads. J. Mater. Chem. A 2019, 32, 18285-18294. [CrossRef]

32. Oh, J.-Y.; You, Y.-W.; Park, J.; Hong, J.-S.; Heo, I.; Lee, C.-H.; Suh, J.-K. Adsorption characteristic of benzene on resin-based activated carbon under humid conditions. J. Ind. Eng. Chem. 2019, 71, 242-249. [CrossRef]

33. Eun, H.C.; Yang, H.C.; Cho, Y.Z.; Lee, H.S. Study of stable destruction method of radioactive waste ion exchanges. J. Radioanal. Nucl. Chem. 2009, 281, 585-590. [CrossRef]

34. Wang, J.; Wan, Z. Treatment and disposal of spent radioactive ion-exchange resins produced in the nuclear industry. Prog. Nucl. Ener. 2015, 78, 47-55. [CrossRef]

35. Zhang, X.; Gu, P.; Liu, Y. Decontamination of radioactive wastewater: State of the art and challenges forward. Chemosphere 2019, 215, 543-553. [CrossRef]

36. Choi, W.N.; Lee, U.; Kim, H.R. Radiological assessment on spent resin treatment facility and transportation for radioactive waste disposal. Prog. Nucl. Ener. 2020, 118, 103125. [CrossRef]

37. Kociołek-Balawejder, E.; Stanisławska, E.; Jacukowicz-Sobala, I.; Baszczuk, A.; Jasiorski, M. Deposition of spherical and braceletlike $\mathrm{Cu}_{2} \mathrm{O}$ nanoparticles within the matrix of anion exchanges via reduction of tetrachlorocuprate anions. J. Environ. Chem. Eng. 2020, 8, 103722. [CrossRef]

38. Jacukowicz-Sobala, I.; Stanisławska, E.; Baszczuk, A.; Jasiorski, M.; Kociołek-Balawejder, E. Size-controlled transformation of $\mathrm{Cu}_{2} \mathrm{O}$ into zero valent copper within the matrix of anion exchangers via green chemical reduction. Polymers 2020, $12,2629$. [CrossRef]

39. Kociołek-Balawejder, E.; Stanisławska, E.; Jacukowicz-Sobala, E.; Jasiorski, M. Anomalous effect of $\mathrm{Cu}_{2} \mathrm{O}$ and $\mathrm{CuO}$ deposit on the porosity of a macromolecular anion exchanger. J. Nanopart. Res. 2021, 23, 126. [CrossRef]

40. Kociołek-Balawejder, E.; Stanisławska, E.; Mucha, I. Effect of the kind of cupric compounds deposit on thermal decomposition of anion exchangers. Thermochimica Acta 2021, 695, 178812. [CrossRef]

41. Kociołek-Balawejder, E.; Stanisławska, E.; Mucha, I. Weakly hydrated anion exchangers doped with $\mathrm{Cu}_{2} \mathrm{O}$ and $\mathrm{Cu}^{0}$ particlesthermogravimetric studies. Materials 2021, 14, 925. [CrossRef]

42. Gawande, M.B.; Goswami, A.; Pelpin, F.X.; Aselfa, T.; Huang, X.; Silva, R.; Zou, X.; Zboril, R.; Varma, R.S. Cu and Cu-based nanoparticles: Synthesis and applications in catalysis. Chem. Rev. 2016, 116, 3722-3811. [CrossRef]

43. Zhao, J.; Shi, R.; Quan, J.; Liu, J.; Wang, J.; Pei, Y.; Wang, X.; Li, Z.; Ren, J. Highly efficient synthesis of dimethyl carbonate over copper catalysts supported on resin-derived carbon microspheres. Chem. Eng. Sci. 2019, 207, 1060-1071. [CrossRef]

44. Deka, P.; Borah, J.B.; Saikia, H.; Bharali, P. Cu-based nanoparticles as emerging environmental catalysis. Chem. Rec. 2019, 19, 462-473. [CrossRef]

45. Kociołek-Balawejder, E.; Stanisławska, E.; Jacukowicz-Sobala, I. Synthesis and characterization of CuO-loaded macroreticular anion exchange hybrid polymer. React. Funct. Polym. 2016, 100, 107-115. [CrossRef]

46. Kociołek-Balawejder, E.; Stanisławska, E.; Jacukowicz-Sobala, I.; Ociński, D. CuO-loaded macroreticular anion exchange hybrid polymers obtained via tetrachlorocuprate(II) ionic form. Int. J. Polym. Sci. 2017, 2017, 4574397. [CrossRef]

47. Kociołek-Balawejder, E.; Stanisławska, E.; Ociński, D.; Winiarska, $\mathrm{K}$. $\mathrm{CuO}$ and $\mathrm{Cu}_{2}(\mathrm{OH})_{3} \mathrm{Cl}$ loaded gel-type anion exchange hybrid polymers obtained via tetrachlorocuprate ionic form. J. Environ. Chem. Eng. 2017, 5, 5668-5676. [CrossRef] 
48. Feng, Z.; Sun, T. A novel selective hybrid cation exchanger for low-concentration ammonia nitrogen removal from natural water and secondary wasterwater. Chem. Eng. J. 2015, 281, 295-302. [CrossRef]

49. Kravchenko, T.A.; Chayka, M.Y.; Konev, D.V.; Polyanskiy, L.N.; Krysanov, V.A. The influence of the ion-exchange groups nature and the degree of chemical activation by silver on the process of copper electrodeposition into the ion exchanger. Electrochimica Acta 2007, 53, 330-336. [CrossRef]

50. Kravchenko, T.A.; Sakardina, E.A.; Kalinichev, A.I.; Zolotukhina, E.V. Stabilization of copper nanoparticles with volume- and surface-distribution inside ion-exchange matrices. Russ. J. Phys. Chem. 2015, 89, 1648-1654. [CrossRef]

51. Cavaco, S.A.; Fernandes, S.; Quina, M.M.; Ferreira, L.M. Removal of chromium from electroplating industry effluents by ion exchange resins. J. Hazard. Mater. 2007, 144, 634-638. [CrossRef]

52. Bezzina, J.P.; Ogden, M.D.; Moon, E.M.; Soldenhoff, K.L. REE behavior and sorption on weak acid resins from buffered media. J. Ind. Eng. Chem. 2018, 59, 440-455. [CrossRef]

53. Choi, J.-W.; Song, M.-H.; Bediako, J.K.; Yun, Y.-S. Sequential recovery of gold and copper from bioleached wastewater using ion exchange resins. Environ. Pollut. 2020, 266, 115167. [CrossRef]

54. Chen, X.; Li, Q.; He, H.; Zhang, J.; Mao, Z. Effect of ion form of the ion-exchange resin on $\epsilon$-poly-l-lysine purification from microbial fermentation broth. RSC Adv. 2019, 9, 12174-12188. [CrossRef]

55. Chen, J.; Liu, H.; Xia, Z.; Zhao, X.; Wu, Y.; An, M. Purification and structural analysis of the effective anti-TMV compound $\varepsilon$-poly-L-lysine produced by Streptomyces ahygroscopicus. Molecules 2019, 24, 1156. [CrossRef] [PubMed]

56. Chugunov, A.S.; Nechaev, A.F. Potential use of carboxyl ion exchangers for operational optimization of special water purification systems in NPP with VVER. Atom. Energy 2015, 118, 224-228. [CrossRef]

57. Vinnitskii, V.A.; Chugunov, A.S.; Nechaev, A.F. Prospects for using weakly dissociated ion exchange resins in special water treatment systems at VVER-based nuclear power plants for reducing the volume of radioactive waste generated. Therm. Eng. 2018, 65, 212-216. [CrossRef]

58. Dorfner, K. Synthetic ion exchange resins. In Ion Exchangers; Dorfner, K., Ed.; Walter de Gruyter: Berlin, Germany, $1991 ;$ p. 222.

59. Dubois, M.A.; Dozol, J.F.; Nicotra, C.; Sereze, J.; Massiani, C. Pyrolysis and incineration of cationic and anionic ion-exchange resins-Identification of volatile degradation compounds. J. Anal. Appl. Pyrol. 1995, 31, 129-140. [CrossRef]

60. Kociołek-Balawejder, E.; Stanisławska, E.; Mucha, I. Freeze dried and thermally dried anion exchanger doped with iron(III) (hydr)oxide-Thermogravimetric studies. Thermochimica Acta 2019, 680, 178359. [CrossRef]

61. Idiţoiu, C.; Segal, E.; Chambree, D. Kinetics of non-isothermal behavior of synthetic cationites with low acidity. J. Therm. Anal. Calorim. 1999, 56, 407-417. [CrossRef]

62. Chambree, D.; Idiţoiu, C.; Segal, E.; Cesario, A. The study of non-isothermal degradation of acrylic ion-exchange resins. J. Therm. Anal. Calorim. 2005, 82, 803-811. [CrossRef]

63. Chambree, D.; Idiţoiu, C.; Segal, E. Non-isothermal dehydration kinetics of acrylic ion-exchange resins. J. Therm. Anal. Calorim. 2007, 88, 673-679. [CrossRef]

64. Bogoczek, R.; Pińkowska, H. Covalent reactions on carboxylic cation exchangers poly(acrylic acid-dvb/esters). React. Funct. Polym. 2003, 54, 117-130. [CrossRef]

65. Bogoczek, R.; Pińkowska, H. Chemical modification of acrylic acid and divinylbenzene copolymers. In Synthesis of polymeric acrylic anhydrides. Part I; Lviv Polytechnic National University: Lviv, Ukraine, 2000; pp. 42-57. 